\title{
THE UTILIZATION OF INSTRUCTIONAL MULTIMEDIA FOR ENGLISH LEARNING
}

\author{
Rizki Farani \\ Islamic University of Indonesia
}

\begin{abstract}
Technology is one of the instructional components in almost all teaching and learning processes, including English learning. However, the utilization of technology in English Learning needs specific methodological procedures to develop appropriate media for students. This paper will discuss about the utilization of instructional multimedia in English learning by describing the concept of multimedia, instructional multimedia in English learning and the application of instructional multimedia utilization in the class. The application is based on a research, conducted in STAIN (State Islamic Institute) Samarinda in March 2012. The research involves several procedures in using multimedia in Reading class. The media is CD product, developed by using software Macromedia Flash 8 and Cool Edit Pro.
\end{abstract}

Key words: instructional multimedia, English learning, macromedia flash 8

\section{INTRODUCTION}

Technology changes very rapidly in globalization era, especially in education field. Technology has become one of the instructional components in almost all teaching and learning processes, including English learning. Nowadays, most English teachers or educators utilize instructional multimedia in presenting four English skills (Listening, Speaking, Reading and Writing). Today, multimedia in English learning is not only limited to Listening Laboratory but also LCD, computer or television. This paper will discuss deeply about the utilization of instructional multimedia for English learning based on several discussion such as the concept of instructional multimedia, instructional multimedia in English learning and the application of instructional multimedia utilization in English learning. 


\section{DISCUSSION}

\section{The Concept of Instructional Multimedia}

Instructional Multimedia is a presentation of materials through words and pictures. The words are presented in verbal form, such as printed or spoken words, while the images are presented in the form of static and dynamic graphics, such as illustrations, photos, animation or video (Mayer, 2007: 3). This opinion is supported by Smaldino et. al (2005: 141) who state that multimedia refers to the sequential or simultaneous use of a variety of media formats in a given presentation or self-study program. Winarno also states that (2009: 8) multimedia is a combination of text, images, graphics, animation, audio and video, and interactive delivery method that can create the learning experience for students as in real situation. Based on these definitions, instructional multimedia is media presentation for learning process. It usually includes text, images, audio, video and animation. There are several kinds of instructional multimedia, such as:

a. Multimedia kits, which is a collection of materials involving more than one type of medium and organized around a single topic.

b. Hypermedia. A media that allow the composition and display of non sequential materials.

c. Interactive media refers to media that require learners to practice skills and receive feedback.

d. Virtual reality. A media in which users experience multisensory immersions and interact with phenomena as they would in the physical world.

e. Expert systems. A software packages that teach learners how to solve a complex problem by applying the collective wisdom of experts in a given field.

(Smaldino,et.al, 2005: 142)

The utilization of instructional multimedia gives positive impact in a learning process because multimedia can be developed based on different learning situation and students' learning style (Sri Anitah: 2010: 57). Specific development of instructional multimedia can help to improve student's achievement in the learning process.

\section{Instructional Multimedia in English Learning}

Instructional multimedia in English learning can be used in a variety of ways to enhance the teaching of many aspects of reading and writing particularly. These 
might include using program designed to enhance students' understanding of text, websites, word processing for effective drafting and redrafting of work, using software to design media texts (newspaper and magazines), using digital or recording camera to create visual presentations, using media hardware to create and edit moving images, using recording equipment to create audio- resources (tapes or CDs), designing websites and creating online texts (email and blog) (Warham, 2009: 183).

However, the utilization of instructional multimedia should consider several aspects, such as learning objectives and students' learning style. In terms of learning objectives, English as a foreign language usually focuses on understanding English as one of academic competencies. Meanwhile, English as a second language usually focuses on literacy and the goal of the instruction is learning how to use English (Gebhard, 2005: 3). Thus, the utilization of instructional multimedia should help student to comprehend English in all skills or communicate by using target language. Moreover, students' learning style also can be basic consideration before using multimedia in the class. Learning styles can be categorized in four variables;

a) Perceptual preferences and strengths. This variable includes auditory, visual, tactile and kinesthetic.

b) Information processing habits. This category includes a range of variables related to how individuals tend to approach the cognitive processing of information. It includes concrete sequential, concrete random, abstract sequential and abstract random.

c) Motivational factors. Motivation can be categorized as either intrinsic or extrinsic motivation.

d) Psychological factors. These factors relate to gender differences, health and environmental condition.

(Smaldion, et.al, 2005: 51-52)

Based on the description above, a specific and complete procedure in utilizing instructional multimedia in English learning can be conducted in several steps (Borg \& Gall: 1983:775):

1. Product analysis. This step includes survey, observation or interviews to identify problems and demands in English learning. The data can be used to determine an appropriate solution for those problems. 
2. Product development. This step includes; a) determining material, method and media; b) collecting the multimedia aspects such as text, images, audio, video or animation; c) designing a flowchart and storyboard to visualize the product.

3. Field testing and product revision. This step includes; a) conducting field test to gain students' impression about product and b) revise the product based on students' comments or suggestions.

4. Determining final product. In this step, an instructional product is revised to get final media. The revision is not only based on students' suggestion but also based on media or content experts' suggestion.

5. Product utilization. After developing a final product, the product is ready to be used in learning process in the class. To maximize the results of learning, it is suggested to give pre-test and post-test to the students. These tests are used to analyze the impact of using instructional multimedia. This data is important as a part of media evaluation.

\section{The Application of Instructional Multimedia Utilization in English Learning}

In this paper, the application of instructional multimedia utilization in English learning focuses on developing CD (Compact Disk) product for Reading Courses in STAIN (State Islamic Institute) Samarinda. It is based on a research, conducted in March 2012. The development of multimedia product included several steps as follows:

\section{Product Analysis}

This step was data collecting through survey, observation and interview, to identify the problems in English learning. The result showed that the implementation of English language learning in STAIN Samarinda was not effective. One of the factors was limited media in learning process. The resource in learning process was only book or module, written by faculty members in STAIN. As the impact of limited learning resource, students were not active and less interested in learning English. This fact was shown based on small-scale survey, conducted in April 2010. The survey showed that 90\% of students preferred learning Arabic than learning English. In fact, STAIN has a good potential to improve the quality of English language learning because STAIN has infrastructure, facilities and media. In terms of media, STAIN has several media to support English language learning, such as computer laboratory, language 
laboratory, tape recorder, LCD, e-academic system and webmail. By using these media, STAIN has a great opportunity to use many instructional media for English classes. Based on this condition, it is suggested to develop a CD product to maximize the usage of computer laboratory in STAIN Samarinda.

\section{Developing Preliminary Product}

This step included collecting English content, collecting multimedia aspects such as images and audio, designing flowchart and storyboard to visualize the concept of product. Several examples of flowchart and storyboard are as follows:

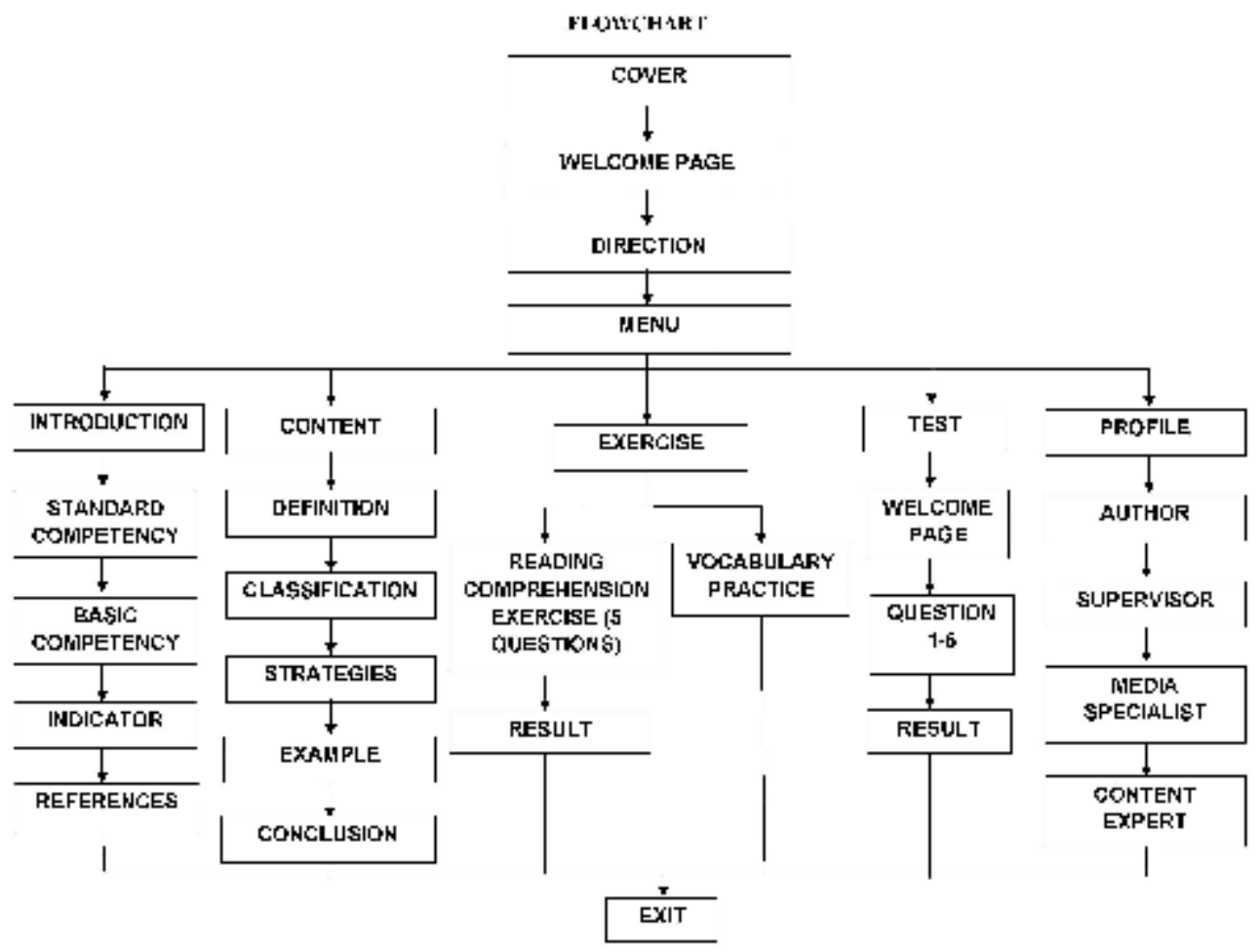




\section{SIOKYIKOARI)}

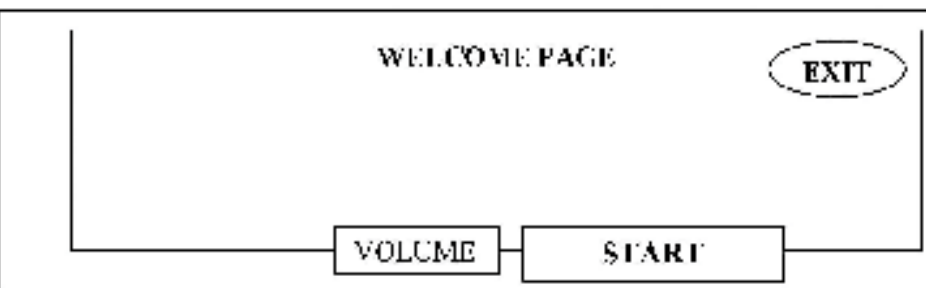

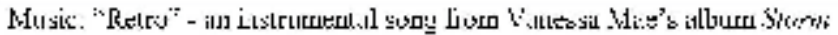

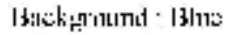

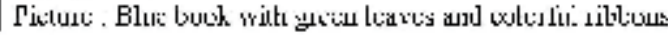

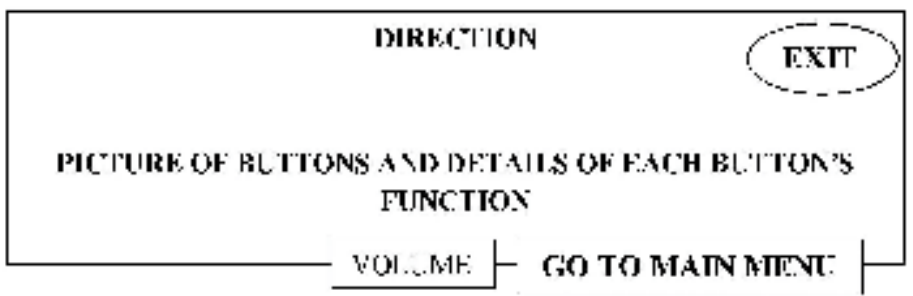

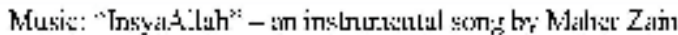
Hackeround - Hilpe

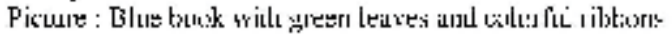

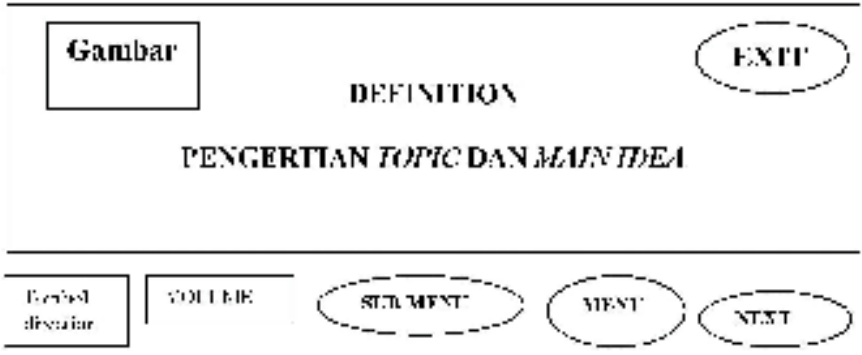

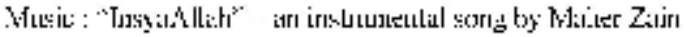

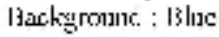

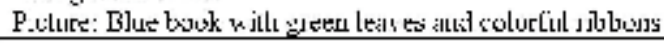


As the result of resources collecting, the preliminary product was instructional $\mathrm{CD}$ for Reading course. The title is Topic and Main Idea. This product was developed by using software Macromedia flash 8 (Gay, 2001: 1) and Cool Edit Pro. The general characteristics of the product are as follows:

a. The method, used to present the material is tutorial method in computer program. This method includes the sequence of material presentation such as the basic concepts of topic and main idea in a reading passage, the examples of analyzing topic and main idea, exercises and tests. The material also presents some examples of paragraphs to help students analyze topic and main idea and provide feedback and tests based on students' answers.

b. This product has several aspects that make it easier for students to study Reading, for example; instructional instructions, containing standard competency, basic competency and indicators; learning materials; examples and exercise.

c. The product is interactive product $\mathrm{CD}$. This product requires students to involve actively in the learning process.

d. The product can be used Products can be used for students' self-learning. Students can study individually without lecturers.

\section{Expert Validation and Revision}

To determine the quality of preliminary product, content and media expert analyzed the product and gave some revisions. The experts were English lecture and media expert in certain university. This step is necessary to validate the product in terms of English content, such as grammatical error, accuracy and references; and media visualization, such as images and audio.

Based on the result, the preliminary product was categorized as a good multimedia for English learning. This result was gained from five-scale questionnaire. In English content, the score of the product was 3,95 (good) and in media aspect, the score was 4,72 (very good).

\section{Field Testing and Revision}

After the validation process, the product should be tested among students as the users of the product. Field test aims to gain students' opinion about product. The procedure of the test was conducting learning process by using CD product and 
asking students to fill the questionnaire as a part of revision process. There are three steps of field testing; individual test, small group test and large group test. Individual test involves 3 students who studied by using CD product and gave their comments through the questionnaires. Small group test involves 10 students who also studied by using CD product and gave their opinion. Large group test involves 20 students who used similar CD to study reading comprehension about Topic and Main idea. The results showed that the quality of CD product was good. By using five-scale questionnaire, it was found that the score was 4, 02 for individual test, 3, 6 for small group test and 3, 81 for large group test.

\section{Final Product Revision}

After conducting field test, the final product was revised based on experts' suggestion and students' opinion. The revision includes all aspects, such as English content, images, audio and text. The final product was ready to be used in the real learning process in the class. Several examples of CD product are as follows:

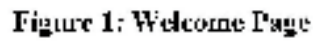

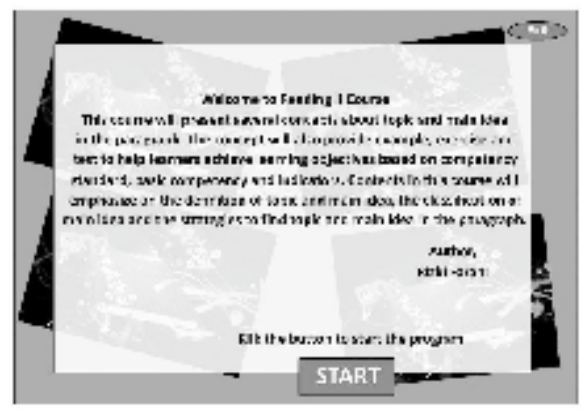

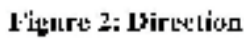

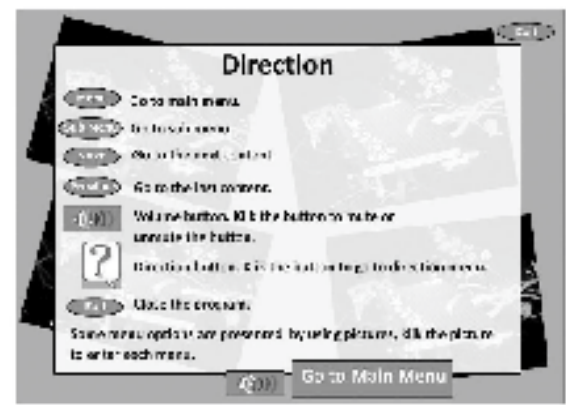


Fignre 3: Cnntent

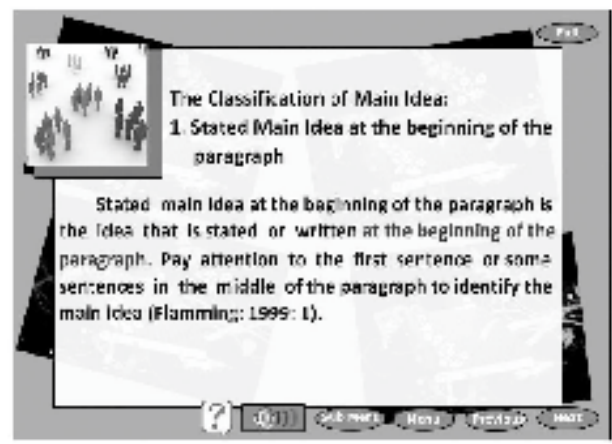

\section{Figure: 4: Test}

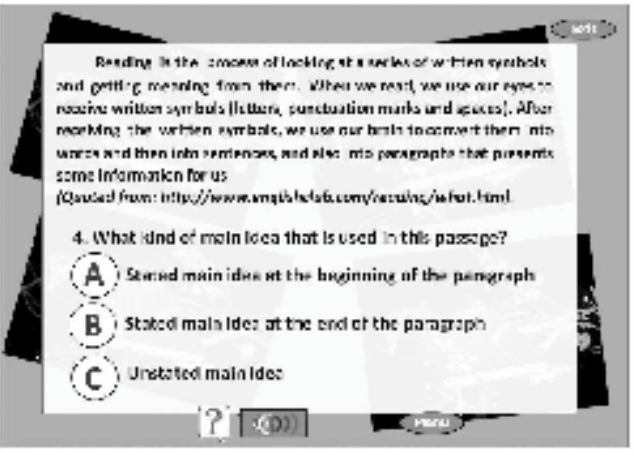

Figure 5: Anstrer Kự

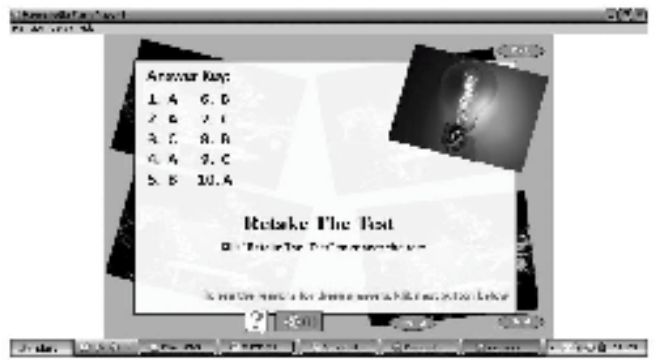




\section{Product Utilization}

The instructional CD product was used in Reading course, involving 30 students in a class. In this process, lecturer did not deliver the materials but students studied the materials by themselves. Since the method focused on individual learning, the course used specific lesson plan that also orientated to individual learning and the utilization of instructional multimedia in English learning. The example of lesson plan was as follows:

\section{Lesson Plan}

Course : Reading II

Credit : 2

Content : Topic and Main

Competency Standard: Student can understand paragraph by analyzing topic and main idea

\section{Basic Competency, indicators and learning objectives}

a. Competency Standard: Student can understand a paragraph by analyzing topic and main idea.

b. Basic Competency: Students can analyze topic and main idea in a paragraph.

c. Indicator:

a. Students can understand the definition of topic and main idea (C2).

b. Students can understand the differences between topic and main idea (C2).

c. Students can understand three kinds of main idea (C2).

d. Students can apply the strategies to identify topic and main idea in a paragraph $(\mathrm{C} 3)$.

e. Students can analyze topic and main idea in a paragraph (C4).

d. Learning Objectives : Student can analyze topic and main idea in paragraphs

\section{Content/ Material:}

\section{a. The definition of topic and main idea.}

Topic is the word or phrase that best describes what all of the sentences in the paragraph are about. Words relating to the topic are usually repeated several times in a paragraph. Looking for these words can help you focus on the topic. 
Meanwhile, main idea is the idea that the writer wants to express about the topic. Based on the definition, it can be concluded that topic is different from main idea:

1. Topic is more general than main idea;

2. Topic focuses on general theme or message and main idea emphasizes on specific "key concept" being expressed. (Mikulecky \& Jeffries: 2007: 105, Academic Support Guides-Cuesta College: 2003:1).

\section{b. The classification of main idea:}

1. Stated main idea at the beginning of the paragraph. Stated main idea at the beginning of the paragraph is the idea that is stated or written at the beginning of the paragraph. Pay attention to the first sentence of the paragraph or some sentences in the middle of the paragraph to identify the main idea (Flamming: 1999: 1).

2. Stated main idea at the end of the paragraph.

Stated main idea at the end of the paragraph is the idea that is stated or written at the last part of the paragraph. Pay attention to the last sentence of the paragraph. It usually states as a conclusion or summary from previous information that is described in the paragraph (Flamming: 1999: 1).

3. Unstated main idea.

Unstated main idea is the idea that is not stated or written on the text. The writer's idea may be expressed in several sentences in the paragraph. In this case, reader must combine ideas from several sentences to infer the complete main idea (Mikulecky \& Jeffries: 2007: 110).

\section{c. Strategies in finding topic in a paragraph:}

1. Focus on general theme or idea.

2. Pay attention to the words that are repeated several times.

\section{d. Strategies in finding main idea in a paragraph:}

1. Define the general topic.

2. Pay attention to the beginning, the middle or the last part of a paragraph.

3. Pay attention to idea that is repeated in different sentences (e.g. synonym).

4. For unstated main idea, pay attention to one or more sentences and combine ideas from several sentences to conclude the main idea. (Mikulecky \& Jeffries: 2007: 105, Academic Support Guides-Cuesta College: 2003:1, Flamming: 1999: 1). 
Meanwhile, main idea is the idea that the writer wants to express about the topic. Based on the definition, it can be concluded that topic is different from main idea:

1. Topic is more general than main idea;

2. Topic focuses on general theme or message and main idea emphasizes on specific "key concept" being expressed. (Mikulecky \& Jeffries: 2007: 105, Academic Support Guides-Cuesta College: 2003:1).

\section{b. The classification of main idea:}

1. Stated main idea at the beginning of the paragraph.

Stated main idea at the beginning of the paragraph is the idea that is stated or written at the beginning of the paragraph. Pay attention to the first sentence of the paragraph or some sentences in the middle of the paragraph to identify the main idea (Flamming: 1999: 1).

2. Stated main idea at the end of the paragraph.

Stated main idea at the end of the paragraph is the idea that is stated or written at the last part of the paragraph. Pay attention to the last sentence of the paragraph. It usually states as a conclusion or summary from previous information that is described in the paragraph (Flamming: 1999: 1).

3. Unstated main idea.

Unstated main idea is the idea that is not stated or written on the text. The writer's idea may be expressed in several sentences in the paragraph. In this case, reader must combine ideas from several sentences to infer the complete main idea (Mikulecky \& Jeffries: 2007: 110).

\section{c. Strategies in finding topic in a paragraph:}

1. Focus on general theme or idea.

2. Pay attention to the words that are repeated several times.

\section{d. Strategies in finding main idea in a paragraph:}

1. Define the general topic.

2. Pay attention to the beginning, the middle or the last part of a paragraph.

3. Pay attention to idea that is repeated in different sentences (e.g. synonym).

4. For unstated main idea, pay attention to one or more sentences and combine ideas from several sentences to conclude the main idea. (Mikulecky \& Jeffries: 2007: 105, Academic Support Guides-Cuesta College: 2003:1, Flamming: 1999: 1). 


\section{E. Example:}

\section{Passage 1}

The absolute singleness of God leads Islam to denounce every form of idolatry. Although Muslim believes in Angles, but Angles only consider as the messengers of God, especially God's final message to mankind. Gabriel delivered the words of the Qur'an to Muhammad but it doesn't mean that Muhammad believes in Angles. Muhammad still spoke by the spirit of God as the absolute power (Quoted from: Muhibbin Syah. Islamic English. 2005:199).

Main ideas: The Absolute Singleness of God in Islam

Explanation: This is stated main idea at the beginning of the paragraph. The first sentence mentions the general idea and the next sentences state the additional information about the concept of God in Islam.

\section{Passage 2}

Other than work in the two fields of elucidating vision and assessing contemporary western civilization, the Institute proposes to authorize the preparation of original works by Muslim scholars who are thoroughly acquainted with the legacy, have a command over the modern sciences, and are prominent in creative ability and intellectual independence. All of the characteristics will qualify them to make original contribution to the Islamization of knowledge (Quoted from: Muhibbin Syah. Islamic English. 2005:18).

Main idea: Muslim scholars' characteristics

Explanation: This is stated main idea at the end of the paragraph. The main idea is stated as a conclusion of Muslim scholar characters; mentioned in the previous sentences, e.g. acquainted with the legacy, have a command over the modern sciences, creative and intellectual independence.

\section{Passage 3}

In the seventh and the eight centuries, armies fought in the name of the Muslim empire. It expanded their power into the hearth of Christian world. They occupied the provinces of Byzantine Empire in Syria, the Holy Land and Egypt, and spread westwards into North Africa, Spain and Sicily. The conquest 
was not only a military one, it was followed in course of time by conversion to Islam on a large scale (Quoted from: Muhibbin Syah. Islamic English. 2005:18).

Main idea: The conquest of Muslim empire

Explanation: This is unstated main idea. There are two ideas; 1) Muslim empire and 2) conquest. Muslim empire fought to expand their power. (expand the power $=$ conquest). The main idea is the combination of who (people who do something) and what (thing that people do).

\section{Learning Strategy:}
a. Model
: Self-learning
b. Method
: Tutorial
c. References

1) CD Product

2) Article: Identifying topics, main ideas, and supporting details dari Academic Support Guides from Cuesta College (Academic Support Guides, 2003: 3).

3) Article: Tips for increasing reading comprehension for college students from Ernest Capraro (Capraro, 2007: 1).

4) Article: What is reading from English Club Team (English Club Team, 1997).

5) Article: Main idea from Laraine Flamming (Flamming, 1999: 1).

6) Book: Advanced reading power. Extensive reading. Vocabulary building. Comprehension skills. Reading faster dari Beatrice S. Mikulecky \& Linda Jeffries (Mikulecky \& Jeffries, 2007).

7) Reading Text: Health Benefit of Fasting dari Rhalmi Mohammed (Mohammed, 2009: 1).

8) Book: Islamic English dari Muhibbin Syah (Muhibbin Syah, 2005: 23199).

9) Article: Ten Tips for Identifying Main Ideas Speccis College (Speccis College, 2011: 1).

10) Computer Set 


\section{d. Evaluation: Exercise, test, pretest and posttest}

The example of pre-test and post test is as follows:

\section{Paragraph 1}

Our national history shows that nonformal education such as Islamic boarding schools (pesantren) and missionaries of other religions have been much more succesful in preparing community leaders and propagating religion. The nation is indeed indebted to volunteers, teachers, propagators, informal leaders and social workers at religious institutions and non-governmental organizations whose devotion, dedication and commitment have been taken for granted by the government. (Quoted from : Syah, Muhibiddin. Islamic English, 2005: 89)

1. What kind of main idea that is used in this paragraph?

a. Stated main idea at the beginning of the paragraph.

b. Stated main idea at the end of the paragraph.

c. Unstated main idea.

\section{Paragraph 2}

The absolute singleness of God leads Islam to denounce every form of idolatry. Although Muslim believes in Angles, but Angles only consider as the messengers of God, especially God's final message to mankind. Gabriel delivered the words of the Qur'an to Muhammad but it doesn't mean that Muhammad believes in Angles. Muhammad still spoke by the spirit of God as the absolute power (Quoted from: Muhibbin Syah. Islamic English. 2005: 199).

2. Where in the paragraph does the author describe the topic?
a. Line 1-2
b. Line 2-3
c. Line 3-4

\section{Paragraph 3}

In the seventh and the eight centuries, armies fought in the name of the Muslim empire. It expanded their power into the hearth of Christian world. They occupied the provinces of Byzantine Empire in Syria, the Holy Land and Egypt, and spread westwards into North Africa, Spain and Sicily. The conquest was not only a military one, it was followed in course of time by conversion to 
Islam on a large scale (Quoted from: Muhibbin Syah. Islamic English. 2005:18).

3. What is the topic of the paragraph?
a. The conquest of Muslim empire
b. Muslim empire
c. Muslim army

\section{Paragraph 4}

Zakat is one of the principles in Islam. The word 'zakat' means both 'purification' and 'growth'. In zakat, our possessions are purified by setting aside a portion for those in need and this cutting back balances and encourages new growth. Sharing our possession to others can help us to commit that everything belongs to God (Quoted from: Azhar Arsyad. Step by Step Readings in English for IAIN Students. 2006: 111).

4. What is the main idea of the paragraph?

a. One of the most important principles of Islam is that everything belongs to God

b. The word 'zakat' means both 'purification' and 'growth'

c. Zakat is one of the principles in Islam

Based on the result of pre-test and post-test, the utilization of CD product could improve students' achievement. The students' score average increased from 53, 7 to 74,7 . The implication of this result shows that instructional multimedia is a good media for English learning.

\section{Instructional procedures :}

\section{A. Preliminary Process}

1. Greetings

2. Giving multiple choice tests to the students as a pre-test to determine their preliminary knowledge about the material (topic and main idea).

3. After the test, lecture explained learning objectives and learning procedure (e. g: self- learning by using CD product).

\section{B. Main Process (approximately 60 minutes)}


1. Giving the CDs product to students.

2. Students conducted learning process by using CD product. They studied the material by using computer individually.

3. Lecturer helped students in technical problems.

\section{Closing (approximately 20 minutes)}

1. Open discussion to clarify the understanding of all the materials.

2. Lecture concluded all materials by highliting some important concepts.

3. Giving similar multiple choice tests to the students as a post-test to determine their knowledge after using the product.

\section{CONCLUSION}

Technology can be used as one of the instructional components in English learning. One of the popular technologies is instructional multimedia because multimedia can present material in several aspects such as text, images, audio, video and animation. Instructional multimedia can be developed in CD product by using computer software such as Macromedia Flash 8 . The general characters of CD product are:

1. CD product uses tutorial method in delivering the lesson. The material is presented in specific sequence from instruction, basic concept, example and test.

2. CD product is used for individual learning. Lecturers or educators do not 